\title{
Managing business performance: the contrasting cases of two multiple retailers 1920 to 1939
}

Article

Accepted Version

Hull, A. (2018) Managing business performance: the contrasting cases of two multiple retailers 1920 to 1939. Business History, 60 (7). pp. 959-982. ISSN 1743-7938 doi: https://doi.org/10.1080/00076791.2018.1459251 Available at https://centaur.reading.ac.uk/81635/

It is advisable to refer to the publisher's version if you intend to cite from the work. See Guidance on citing.

To link to this article DOI: http://dx.doi.org/10.1080/00076791.2018.1459251

Publisher: Taylor \& Francis

All outputs in CentAUR are protected by Intellectual Property Rights law, including copyright law. Copyright and IPR is retained by the creators or other copyright holders. Terms and conditions for use of this material are defined in the End User Agreement.

www.reading.ac.uk/centaur 
Central Archive at the University of Reading

Reading's research outputs online 



\title{
Managing Business Performance: the contrasting cases of two multiple retailers 1920 to 1939
}

\author{
Business performance measurement and management (PMM) systems are often \\ viewed as relatively recent phenomena, responding to the failure of historical \\ practices which prioritised financial measures. But despite the considerable focus \\ on these systems over the last 25 years, they have not lived up to their early \\ promise. This paper looks backwards to understand how practitioners managed \\ their performance in the past. It focuses on two British multiple retailers between \\ 1920 and 1939 and highlights not only the formal processes they adopted but also \\ the role of the informal processes which shaped how they achieved their \\ objectives.
}

Keywords: business performance management, business performance measurement, balanced scorecard, retail, business history

\section{Introduction}

In 1992, Robert Kaplan and David Norton published 'The Balanced Scorecard Measures that Drive Performance.' The article called for a complete rethink on how companies measure their performance and captured the interest of both academics and practitioners alike. ${ }^{1}$ It was not the first to challenge how firms measure their performance but its popularity triggered what was subsequently described as a 'revolution' which continues to this day. ${ }^{2}$ However, while the subject may have had its roots in measurement, it has evolved and broadened over the last 25 years. Lebas argued that performance measurement is inseparable from performance management as one creates the context for the other. ${ }^{3}$ Kaplan and Norton's own contributions have shifted from an emphasis on measurement systems to management systems where measurement is just one part of a wider system. ${ }^{4}$ Similarly, Bititci et al. placed performance measurement within a wider performance management system. In their 
widely-cited definition, they describe a process by which the company manages its performance in line with its corporate and functional strategies and objectives. And, the performance measurement system, which forms part of it, provides the feedback to make appropriate management decisions. ${ }^{5}$ It is this wider context that is the subject of this paper and will be referred to as performance measurement and management $(\mathrm{PMM}){ }^{6}$

Despite the considerable focus on PMM systems over the last 25 years, it is not clear that they have been a success in practice. Firms have struggled to implement systems and research has failed to provide consistent evidence that these systems actually improve performance. ${ }^{7}$ H.T. Johnson, whose work with Kaplan on 'Relevance Lost' did so much to trigger the performance measurement revolution, has gone even further. Provocatively, he concludes that not only are measures and targets not needed to manage performance but that the on-going focus on them can harm the long-term performance of the organisation. ${ }^{8}$ Some of the most published researchers in the field now question our current understanding of PMM. They argue that the discipline is at a 'cross-roads', that 'our understanding of this field is far from complete' and requires 'a complete re-think' ${ }^{9}$

In considering the issues, the literature too often overlooks the experience of firms in the past. Consideration of how to manage performance and how to use the statistics increasingly available to them has long been a concern for organisations, particularly as they developed from small-scale to large scale and from single-unit to multi-unit businesses. The conventional narrative describes the focus of pre-1960's performance measurement and management on the supply side; costs needed to be minimised, work was primarily manual and management systems were based on prescriptive procedures and controls. ${ }^{10}$ However, this understates the importance of the 
service sector and particularly the large-scale retail sector which emerged at the end of the 19th century. Their management practices focused on the demand side: on the customer and the 'knowledgeable' employee who had to understand not only their customers but also the products they had (or had to acquire) to meet their changing needs. In multiple retail, managing the performance of the business was further complicated by distance. Head Offices were not only distant from their customers but also their employees who were responsible for managing the relationship with the customer.

This paper will compare the experiences of two British multiple retailers between 1920 and 1939 to understand how they used measures and managed their performance during a volatile period economically but innovative period managerially. Boots Pure Drug Company (Boots) and WH Smith and Sons (WHS) were already wellestablished firms by 1920 . WHS, founded in 1792, was a traditionally managed firm with structures which had evolved slowly over the previous century. In 1920, it was still owned by the Smith family and managed by a small group of Partners comprising family members or close family friends. In contrast, Boots was bought by the United Drug Company of the United States in 1920 and immediately introduced the innovative structures of its parent company's retail business (Liggett's). In comparing the PMM structures of the two firms, the aim is not to identify the differences but rather the similarities and, in understanding these, to provide insights which may help answer questions being raised about modern PMM systems.

\section{Approach}

To compare the two firms, data collection, analysis and presentation has been informed by Ferreira and Otley's 'extended framework for analysis of performance management systems'. ${ }^{11}$ The framework was developed as a research tool for describing the structure 
and operations of these systems in a holistic manner and was based on an earlier model developed by Otley. ${ }^{12}$ It was a response to criticism that much of the existing research into PMM's had been based on simplified and partial settings. ${ }^{13}$

The framework has been modified to avoid obviously anachronistic terminology and some of the separate elements in Ferreira and Otley's framework have been merged to simplify presentation. The framework is based on a series of questions grouped under the principal components of a PMM system (see table 1).

\section{Table 1: Framework (near here)}

Although the framework was developed to help researchers conduct case studies on modern management structures and processes, it has been used in this paper to facilitate a comparative historical study. The interplay of past and present has long been a feature of historiography and understanding the present including frameworks, methods and theories, are considered by some to be essential to understanding the past. ${ }^{14}$ This becomes increasingly important as historians engage with other management disciplines with different epistemological approaches. The differences, however, rather than barriers to co-operation, can alternatively represent opportunities for both to explore new ways of working and to generate different types of scholarly understanding. ${ }^{15}$ Kipping and Üsdiken, for example, have highlighted how models and frameworks have been used to improve our understanding of the past. But, this understanding has in turn developed a historical cognizance among those investigating organizational and management phenomena. ${ }^{16}$

However, the use of a modern framework poses some risks. First, it can imply a normative structure. This is a particular risk in PMM where a number of the frameworks developed over the last 30 years, such as the Balanced Scorecard, were explicitly 
created to improve the link between strategy and operations. Ferreira and Otley, although acknowledging the risk, emphasise that their framework is simply a heuristic tool which helps to document the 'as is' rather than describing the 'what should be' and does not pre-suppose that a system is already in place.

Secondly, using a modern framework could be considered anachronistic. However, other than changes in the terminology, there is sufficient evidence to suggest that both businesses and contemporary academics considered performance holistically during the period of this study (1920 to 1939). The growth in multiple retail after the First World War generated considerable innovation in management practices with substantial input from management academics. Harvard produced its first volume of retail case studies in 1922 and these were revised regularly over the following 20 years. ${ }^{17}$ The pace of change was such that some academics were left despairing: 'Control methods in large retail establishments are at present in such a state of continuous flux that it seems almost futile to attempt a consideration of the subject in a book' ${ }^{18}$ While the books and articles were not structured in the same way as the framework, their coverage was as broad. Hayward and White, for example, described the 'principles' of chain store management rather than the objectives and referred to alleviating 'problems' rather than improving performance. However, the solutions they described could populate the framework. The chapter on 'Centralising Executive Control' showed, for example, the hierarchical structure below the Executive, the financial and non-financial measures generated for the Executives and the timing and frequency of meetings used to evaluate the measures. ${ }^{19}$ Business historians such as Chandler, Jones and Fear have also shown that businesses have long thought about their structures holistically and the linkages between strategy, structure, operations and culture. ${ }^{20}$ 


\section{The Case Studies}

Boots and WHS were both well established and successful multiple retailers by 1920. However, their evolutions had been quite different (see table 2). Although WHS was the much older firm, it had seen little evolution in its organizational structures and, following Grenier, still adopted an individualistic management style while in Boots, the crisis of leadership brought about by the American acquisition created a more directive style. $^{21}$

\section{Table 2: Chronological summary (near here)}

\section{Boots Pure Drug Company}

In 1920, Boots was sold by its founder, Jesse Boot, to the United Drug Company of the United States. He had built up the business from a single store in Nottingham selling herbal remedies in 1863 to the largest chain of retail Chemists in the World by $1906 .{ }^{22}$ Boot was a discount retailer - he bought directly from manufacturers and undertook some manufacturing himself, aggressively advertised his competitive prices and rapidly expanded the number of branches. ${ }^{23}$ In 1920, Boot accepted an offer for the business from Louis Liggett of the American firm, United Drug Company. ${ }^{24}$ Although the largest drug store chain in the United States, United Drug's retail operations (Liggett's) were

relatively small with only 211 stores. ${ }^{25}$ The Americans retained control until 1933 when financial problems in their own country forced a disposal and Boots once again became a public company.

Apart from reorganizing the business in the early 1920's, the Americans left the running of the business to an Executive Committee led by Jesse Boot's son, John. He 
became Joint Managing Director in 1920 and ran the business after the Americans sold it until his retirement in $1953 .^{26}$

\section{Performance objectives}

In 1921, any reader of the editorial in the first edition of a new company magazine, The Bee, would have had little doubt about the objectives of the company: 'But our whole living - our salaries - our reputation are summed up in our magazine slogan - more sales.' On the opening page, the Sales Manager exhorted 'colleagues and salesmen' to 'LET US GO AFTER MORE VOLUME IN REAL EARNEST.' ${ }^{27}$ It was a theme repeated in articles over the coming months and years. It was consistent with the firm's history and the objectives of the US parent company. It was an objective which lasted well beyond the period covered by this paper; in 1966, the Managing Director conceded that 'regrettably, when it comes to the pinch many of our people still react in the traditional Boots way of sales at any price. ${ }^{28}$

Sales growth was achieved through driving volume and the terms 'sales' and 'volume' were used interchangeably. Products were heavily promoted and they prided themselves on customer service. 'The customer is always right' stressed John Boot's 'Service Letter No. 1' and store managers could not refuse customers a product refund without referring to Head Office. ${ }^{29}$

Improvement in gross margin and control over costs were also important objectives of the organization but less prominent in communications. Margin in particular was a priority for Head Office senior managers. Sales volume allowed the business to secure supplier discounts but the business had also manufactured its own products since the 1880 's. A new factory completed in the early 1930 's contributed to a substantial increase in 'own-goods' production. ${ }^{30}$ And, although enabled by sales 
volume, it was gross margin improvement which was the single biggest contributor to the significant profit improvement between 1922 and $1939 .{ }^{31}$

\section{Organisational Structure}

Prior to the American acquisition, Jesse Boot had run a business with little formal structure. ${ }^{32}$ The Americans brought organisation. George Gales was seconded from the American business and appointed Managing Director. Gales was a strong advocate of organisation ('the greatest asset we have is organisation, greater in value than all the other assets combined') and introduced Liggett's 'American' system. ${ }^{33}$ Two Boots directors (John Boot and Greenwood) toured the US in Autumn 1920 to understand how the system worked in practice. ${ }^{34}$ While Greenwood was disappointed with the quality of the American stores, he was impressed with the organizational structures and in his biography ascribed the financial success of the business in the 1920's to the methods introduced by the Americans. ${ }^{35}$ It was also recognized at the time. In 1923, The Financial Times conceded that 'the introduction of the American element has certainly done the company no harm. It has very much livened up the administration and has modernised executive methods. ${ }^{36}$

The organisation structure was relatively simple, performance oriented and reflected a belief that in a sales based operation, the gap between the shops and directors should be as narrow as possible:

\footnotetext{
'Our present organisation is designed for the purpose of achieving definite business results, and at the same time of achieving those results in the most human and sympathetic manner by obtaining the fullest possible amount of direct personal contact between those responsible for the management of the business and the entire retail staff., 37
} 
It was run as a single unit with no autonomous divisions. In 1920, it was the shops which had the primary responsibility for delivering the performance. Store managers chose those products bought by Head Office suitable for their customers. Store managers, as well as the Executive, were profit accountable while buying departments were not.

Although the company had a Board which included members of the US parent company (and later external directors), it was the Executive Committee who were responsible for the operational management of the retail business. ${ }^{38}$ It had a strong 'performance' bias. The seven members included both a newly created Expense Controller and a Chief Accountant. The Expense Controller (Greenwood) was responsible for store profitability and despite the job title, his remit extended beyond expenses. He frequently visited the stores. In articles for The Bee, he challenged store managers on their overall performance and in his statistical reports, he focused as much on sales and margin as on expenses. ${ }^{39}$ The Accounting Department had a similar performance bias and proudly proclaimed how, through the provision of statistics, they were 'out to make the business as profitable as possible'. ${ }^{40}$ Whatever the department, the focus was on the overall objectives of the business rather than the functions specific role and this was encouraged through competitions such as the annual 'October Cup' where each director took responsibility for three territories and competed with the other directors on who could deliver the biggest sales growth in the month. ${ }^{41}$

Organisationally, the link between the stores and the Directors was provided by Territorial General Managers who reported directly into the Executive; narrow reporting lines offsetting the complications caused by up to 28 people reporting directly to the Executive. ${ }^{42}$ The TGM was a new role created in 1920 and a copy of the American system. ${ }^{43}$ Previously, a team of regional inspectors and auditors had focused on store 
compliance. ${ }^{44}$ The new role was quite different and arguably the core performance oriented role in the new structure. As Gales explained:

'The very size of a business of this kind, and its scattered nature, makes it imperative that everything possible be done to promote contact and understanding between headquarters and branches, and that simple and direct methods be devised to get quick action and decision on important matters. ${ }^{45}$

The TGM was responsible for about 30 stores and the role had two essential components. The first was about knowledge and learning. TGM's were a conduit for information flowing from Head Office to store managers. They also passed on their own knowledge and challenged store managers on their capability. A letter sent to the TGM's in the early 1930's encouraged them to question store managers on operations ('Can you wrap a parcel? Do it.'), selling ('Are you a salesman?’) and staff management ('How much help are you giving your staff'). They encouraged managers to look outwards, challenging them on the average earnings of the local community and the make-up of local industry. ${ }^{46}$ Conspicuously absent in the letter was any reference to how the TGM could use the measures and statistics available in the store. Their local knowledge also flowed upwards. Each TGM wrote a weekly performance report to the Chairman, a practice which continued into the 1960's and, a TGM representative joined the weekly Executive meetings from 1924 because 'it is the desire of the Executive Committee to keep in even closer contact with the Retail Branches. ${ }^{47}$

The second significant component of the TGM role was the management of the people he was responsible for. This included identifying and developing individuals for promotion. When store managers were promoted to TGM, The Bee highlighted the leadership and management qualities rather than any financial successes they had achieved. 


\section{Performance processes}

\section{Planning and targeting performance}

Boots did not produce its first corporate plan until 1978 although it was recognised that informal plans had existed in the past. ${ }^{48}$ While there are no references to even informal plans in the 1920's and 1930's, corporate investment activity, capital forecasting, AGM announcements and internal commentaries suggest the business was following, at the very least, broad long-term principles consistent with their objectives. Operational 'planning' may also have taken place at a local level. TGM's were expected to understand the local economy and competitors, to identify new sites and to encourage new ideas in the stores they were responsible for. ${ }^{49}$

If there were plans, they were not translated into formal targets or budgets for stores. Although multiple retailers in the US were already experimenting with budgets, Boots only used targets (quotas) for short-term sales promotions. ${ }^{50}$ For operational expenditure, managers were given 'standards' to follow on the most significant items salaries (ratio to sales) and purchases (stock standards). ${ }^{51}$ However, these were not so much an operationalisation of plans but controls on expenditure. Otherwise it appears the 'target' was simply to maximise sales growth.

\section{Evaluating performance}

Formally, the Executive met every Tuesday afternoon at 4.00pm to evaluate performance; the timing dictated by the availability of sales information. They were presented with comparative sales, customer numbers and product segmentation. ${ }^{52}$ Interpretation was helped by a TGM attending the meeting and weekly reports from each TGM on the stores they had visited in the week. ${ }^{53}$ However, despite generating monthly and annual statistical reports, there are no other references to monthly, 
quarterly or even annual meetings where performance was formally evaluated. It may have been that they were discussed in the weekly meeting or gaps in the sources.

For evaluating the individual performance of store managers, Boots had formal processes from at least 1922 . The personnel records of store managers included a 'log' of reflections on their performance added to over many years by each Head Office visitor to the store. With three to four entries a year in the 1920's (but fewer in the 1930 's), it was relatively easy to monitor the progress of the manager over several years. Comments were unstructured and subjective (e.g. 'business policy is conservative and he is rather afraid to take a chance'). By 1939, an Annual Staff Report was also completed for all store staff. Staff were graded across 16 qualitative categories ranging from personal qualities (loyalty) to operational capability. ${ }^{54}$ Personnel files also included subjective feedback but, despite the breadth of statistics available, no quantitative measures on the stores run by the manager. In evaluating the performance of store managers, Boots placed more importance on subjective opinions on leadership and operational capability than on the financial performance achieved.

The formal performance evaluation processes were supplemented by informal processes. TGM's visited their stores regularly, providing written feedback to store managers. ${ }^{55}$ Directors and senior managers also visited each branch at least three times a year in the 1920 's. ${ }^{56}$ John Boot claimed to have visited more than 500 stores over just a few months in $1922 .{ }^{57}$ During the annual 'October Cup', a director could visit more than 100 stores in the month. ${ }^{58}$ While these visits may have appeared relatively infrequent from a store manager perspective, when replicated across 1,000 shops, they represented a significant investment in understanding performance.

The insights from these visits represented a considerable body of qualitative knowledge on the performance of the store, the manager and the employees. An article 
written by a TGM in March 1936 highlighted the breadth of knowledge. He provided a list of 37 factors grouped into five categories which helped store managers determine whether they operated a 'five star' branch. Of these factors, less than five were measured (e.g. sales growth). The remainder were subjective and had to be observed evaluating the quality of the staff ('seniors are training juniors'), the level of service ('every customer receives a sympathetic enquiry of needs') and the store environment ('the branch is always clean from front door to back entrance'). ${ }^{59}$

Visiting stores allowed TGM's and Executive directors to not only evaluate whether stores were achieving each of these drivers of performance but also allowed them to understand the complex relationships between the external context, the different drivers of performance and the customer reaction to the overall experience.

\section{Rewarding and motivating performance}

For Executives and senior managers, the American policy was to pay a moderate salary and a profit based bonus. ${ }^{60}$ For store managers, reward was based on a basic salary supplemented by a monthly bonus based on sales growth. Additional bonuses were added if stock standards were maintained (July 1921) and for increases in 'own-goods' sales (1930) although both were contingent on achieving overall sales growth. ${ }^{61}$ Sales assistants' bonus was brought in line in 1936 when sales commission was replaced by a bonus based on growth in total sales and 'own-goods' sales. ${ }^{62}$

Beyond financial rewards, Boots used a range of techniques to motivate performance. John Boot wrote a letter every month to managers awarded a bonus and demonstrated a personal knowledge of every store; he congratulated them on the award but could also, for example, praise their 'nicely dressed windows' or chastise them on their own-goods sales compared to other local stores. ${ }^{63}$ To the store manager, the gap between store performance and the Directors must have seemed narrow. 
The Bee was similarly used to motivate performance and demonstrated the range of symbolic incentives used by the firm. It highlighted examples of individual sales successes, published Honour Rolls (e.g. the Salesmanship Roll of Honour) and comparative lists of Territorial performances. It was also the conduit for promoting the sales tournaments and competitions introduced soon after the American take over. These ranged from small scale inter-store tournaments through to national and international events. Store managers challenged each other: 'Mr. GA Lloyd, on behalf of his branch, 289, Tredegar, wishes to compete with any branch of similar size in the sale of household soaps. ${ }^{\prime 64}$ Larger events were coordinated by Head Office, including three 'Test Matches' where the British stores competed with the American stores on the sales of 'Regefrice. ${ }^{95}$ Rewards varied and included one week's extra salary, a trip to Paris or an annual subscription to a magazine. Often, there was no tangible reward at all other than recognition in The Bee.

The competitions and other techniques helped create a sales culture where staff were praised as 'not mere clerks or shop assistants but Salespeople. ${ }^{66}$ They also brought the shops and Head Office closer together, promoting informal ties. In the annual 'October Cup', first run in 1921, each director took charge of three territories and competed on who could grow sales the most. The Directors visited every one of their stores and The Bee reported their plans, celebrated the winners and interviewed managers about their successful strategies.

\section{Measuring performance (key performance measures)}

Before 1920, Jesse Boot had been concerned about the time it took to generate the statistical records and did not know the profitability of individual stores. ${ }^{67}$ In March 1922, the Accounts Department highlighted the progress made: 
'The Territorial General Managers and the Branch Managers are all supplied with a great number of statistics relating to sales, supplies, stocks, expenses, and other matters.... The work of the Sales Department, the Merchandise and Expense Controls is almost entirely based upon statistics supplied. ${ }^{96}$

Despite the range of statistics generated, 'sales' was the key measure referred to in The Bee, in correspondence with stores and in the various Head Office reports. ${ }^{69}$ Sales measures were widely reported in The Bee including ranking tables of stores and territories. Sales measures also dominated the statistical reporting packs used by the Executive (see table 3). The summary page of the annual statistical book, produced every year from 1925 to 1969 , highlighted the importance of sales measures including volume of sales (customer transactions) and the value of sales (average value and one penny per customer).

Table 3: Boots key performance measures - retail measures reported on the summary page of the Statistical Book (selected years) (near here)

The detailed schedules which followed the summary page were similarly dominated by sales data. In 1939, the book contained 14 sales schedules but only two schedules related to stock and four to expenses. The sales schedules segmented the data geographically, by product and over time. Several schedules listed the sales of individual stores grouped into largest stores, smallest stores, sharpest declining or new stores. Directors could therefore assess the annual sales performance of the overall business (1939: £13.3m) and of the smallest store $(£ 1,507)$ within a couple of pages; emphasising the importance of understanding performance at a unit level. The focus on sales did not reflect weaknesses elsewhere in the reporting systems. The detailed accounting reports demonstrated the level of detail available on expenses, stock and capital expenditure. 
Two features of how Boots used measures stand out. First, there was very little change in the measures reported in the Statistical Books between 1925 to 1939 (and indeed, 1969). There were also no new non-financial measures introduced into the pack after 1925. The lack of new measures was despite investments made elsewhere by Boots in understanding sales and service - in 1929, they employed J Walter Thomson to conduct market research on customers and from 1928 they employed a 'casual customer' who visited shops anonymously and reported regularly in The Bee on the quality of service received. ${ }^{70}$ Secondly, while Boots had the ability to analyse and report margins, stocks and expenses in considerable detail, there was relatively limited reporting in the Statistical Books and little focus on these measures in The Bee or TGM memos. The singular focus helped reinforce the core objectives of the business. As Gales reminded employees, 'sales are the lifeblood of the business. Without sales, there would be no necessity for anything else.' 71

\section{Linking the system}

To what extent did the separate elements link to create what we might call a 'system'? Even a cursory review of the structures and measures highlight the alignment between them and the objectives of the organisation.

The alignment, however, was not just with what needed to be achieved ("MORE SALES") but also how it should be achieved (by narrowing the gap between Head Office and the customer-facing staff). This emphasis highlighted that the stores were the primary units of performance and only by observing how sales growth was delivered in the store, or hearing from those who had observed it directly, could one understand how the various drivers of performance interacted and contributed to the overall performance of the business. 
Encouraging 'closer co-operation and co-ordination' and 'harmonious and sympathetic understanding' between Head Office and the stores also helped develop relationships and loyalty - towards the firm, a store or other employees. ${ }^{72}$ One TGM noted the benefit for store staff of regular store visits by directors: "all realise that members of the Executive are human beings with an intimate knowledge of the difficulties that arise from day to day in the branches." ${ }^{73}$ The Bee (and TGM's) reminded people of the importance of loyalty and its benefits were credited by at least one winner of the October Cup for their success. ${ }^{74}$

In modern PMM systems, it is measures which are credited with linking the separate elements but despite their ability to generate relevant financial and nonfinancial statistics, they played a lesser role in Boots. A clear, simple objective, a focus on directors developing a deep understanding of performance by spending time in the stores and promoting relationships and loyalty played a bigger role.

\section{W.H. Smith and Sons}

WH Smith and Sons (WHS) was an old family firm which had gradually added to its wholesale distribution business by opening bookstalls (from 1848) and retail stores (from 1905). The shops sold books, stationery, newspapers and magazines. It was managed as a partnership until 1929 when, following the death of WFD Smith and the need to raise capital to pay taxes, it became a private limited company. The change to the legal status had little impact on organisational structures and ways of doing things. The Smith family retained the ordinary shares and operationally the firm was managed under the same partnership principles established in the 19th century. Even the terminology remained the same - 'Directors' were still referred to as 'Partners' until the early 1960 's. ${ }^{75}$ Partners and Directors comprised family members and friends of the family. Between 1894 and 1948, every partner/ director appointment was related to an 
existing Partner. ${ }^{76}$

\section{Performance objectives}

In 1936, concerned about his health, the head of the Smith family engaged a firm of solicitors to consider the options for minimising death duties and, in a memo sent to the Partners, the lawyers outlined his principal objectives:

' 1 . that he shall be in the position at his death of passing on the business and its control in as nearly as may be the same condition as that in which he inherited it and;

2. that the future of the present Managing Directors of the Company shall be assured (so far as is reasonably possible) in the event of his dying before them. ${ }^{77}$

The first point appears unambitious; stability over growth. It reflected however, both a financial concern about the on-going viability of the firm and a dynastic determination to maintain a family business which was already 144 years old. It encouraged a risk averse approach to managing the business and was reflected by the firm's cautious approach to investment in the 1920's and 1930's when they repeatedly wrote to senior managers forbidding further capital expenditure. ${ }^{78}$ It was also a view which cascaded through the business and summed up by one senior manager writing to the Partners in 1930: 'well-judged capital expenditure is the first care of every business man.' ${ }^{79}$ It is consistent with Chandler's observation that family owned businesses preferred a steady return over growth.

The second point highlighted the on-going concern the Smith family had for those it employed. Family meant a lot at WHS. A Partner later recalled how 'One cannot help being struck by the family connections among the staff.... I believe there is more than one instance of four generations in direct succession if not five. ${ }^{80}$ Longevity 
of service was similarly prevalent and celebrated in the Firm. A patriarchal care for employees continued well into the 1960's, long after the firm had become a public company. Commenting on David Smith who joined the firm in 1935 and retired as Chairman in 1969, a non-Executive director recalled that 'he was a very fine man who believed himself to be the trustee of the whole business and not just of his family's fortune but of every employee in it. ${ }^{91}$

Growth was a secondary objective. Managers sometimes wrote to the in-house magazine, Newsbasket, highlighting growth opportunities but there were equally others recommending caution. Correspondence between Head Office and with store managers focused on stock levels more than growth and before the 1950's, there were almost no references to the need to grow the business in minutes or speeches.

\section{Organisational structure}

WHS in 1920 was a curious mix of centralised and decentralised operations which lacked an obvious logic. It had evolved slowly over the previous century and when it started opening shops in 1905 , the larger ('A') shops copied the existing Wholesale House structure and the smaller ('B') shops copied the Bookstall structure. These structures did not change until the end of the 1950's.

The Partners sat together in one room and had no specific departmental responsibilities. ${ }^{82}$ Instead, they were expected to have a deep knowledge of all parts of the business but only intervened by exception. This partly reflected a management philosophy which delegated the running of the business to their senior managers. Hornby, a Partner between 1894 and 1946, wrote to a colleague that 'I have always gone on the principle that it is best to let other people do the work and give them full responsibility as a free a hand as possible. ${ }^{, 83}$ In minutes, the performance of the business was rarely mentioned and where it was, erred against intervention. In 1931, 
poor results in the Leeds Wholesale House only warranted sending a manager from Head Office 'unofficially to give advice'. ${ }^{84}$ The following week a Board minute recorded that 'Mr. CH St.J. Hornby spoke strongly against general Head Office interference with Wholesale House expenses. The Manager's own self-interest should be considered sufficient inducement to him to keep expenses down as far as possible. This was generally agreed.' 85 There were few references to performance in subsequent minutes.

At an operating unit level, the Wholesale Houses and larger 'A' shops were run as independent businesses. Each manager was largely free to operate as he chose. As one manager later recalled, 'the A shop manager was the kingpin, he bought what he liked, he sold what he liked at what price he liked. ${ }^{86}$ There were no tiers of management between the store manager and the Partners. Consequently, the Partners had up to 70 separate 'businesses', which accounted for just under half the operating profits, reporting directly into them. ${ }^{87}$

The rest of the business operated through a series of Merchandise Departments run by experienced senior managers who were responsible for buying and supplying the 'B' shops and Bookstalls. Unlike 'A' shops and Wholesale Houses, the 'B' shops and Bookstalls were not profit accountable. They instead focused on sales, controlling expenses and managing stock. Unlike 'A' stores, there were two tiers of management between them and the Partners: 'B' shops and Bookstalls were grouped into a series of districts run by a Superintendent and the Superintendents reported into a Shops/ Bookstalls Manager. Within this structure, the District Superintendent provided the link between Head Office and the individual 'B' stores and Bookstalls. While it was supposed to be a management role, in practice their work included a substantial element of compliance checking and stock counting. 
In Head Office, accounting and provision of statistics was performed by the Balance Department. They saw themselves as a traditional accounting department whose primary responsibility was towards accuracy rather than analysis and interpretation:

'Here the branch balance ledgers and the statistical records are kept in much the same form as they were kept in the days of Mr. WH Smith and his son, his grandson and his great-grandsons. ${ }^{88}$

Not surprisingly, there was little accounting innovation. Central accountants were also expected to have a relatively passive role in performance management. The Chief Accountant was admonished by the Partners in 1919 and 1921 for writing directly to store managers about their figures and instructed that 'No 'propaganda' work should be dealt with by the Balance Department. ${ }^{\text {}}{ }^{89}$ A consultant report in 1956 confirmed that little had changed in the intervening years with more focus on 'accounting finesses than management control.'90

\section{Performance processes}

In general, pre-1940's WHS was a 'process lite' organization with few standardized processes and reliance on the store manager's personal initiative. ${ }^{91}$

\section{Planning and targeting performance}

Before 1940, there was little evidence of formal long term planning and no evidence of any processes in place. The business grew and expanded into new areas but largely as a response to immediate crises/ opportunities and to ideas raised by employees. The 1905 decision to invest heavily in new shops was a response to losing two bookstall contracts. ${ }^{92}$ During the 1920 's and 1930 's, several proposals were presented to the Partners by employees including a mail order business, a cheap bookshop concept and a 
children's bookshop. ${ }^{93}$ The Partners gave serious consideration to the ideas before, in these cases, rejecting them.

There is also no mention of targets, forecasts or budgets before the 1950's. Performance was compared to the past, sometimes over several years and stores were encouraged not to exceed prior year cost to sales ratios. Informally, targeting and financial planning may have been more common in shops but there are few references in the company magazine, Newsbasket, or in correspondence.

\section{Evaluating performance}

In minutes, memoirs and accounting schedules, there is no evidence of any processes in place to regularly evaluate the consolidated performance of the business until the 1950's, despite the Partners meeting at least weekly from 1930. Indeed, it would have been hard to do so. The business could not generate a consolidated sales figure until 1964. ${ }^{94}$ Even at departmental level, the sources are unusually silent on any formal evaluation processes. Instead, performance discussions took place individually. As one Partner recalled:

'all the Superintendents came up once a month to report personally to the Partners and we shared them out between us, and in that way kept in close touch with the progress made by individual branches and got regular assessments of the capabilities of managers and staff.' 95

There was a similar, albeit annual, process for each of the Wholesale House and 'A' store managers. These also lacked process as attested to by one Wholesale House manager who recalled a review taking no more than five minutes with no reference to any measures. It was, however, after a particularly good year - meetings lasted longer in poorer years. ${ }^{96}$ The few references to performance in the minutes primarily related to 
individuals and to specific issues in their store. While the Partners received quarterly reports, and were aware of performance issues, they managed them by exception.

The formal processes, both in terms of evaluating the financial performance of the stores and the personal performance of the manager, may have been relatively underdeveloped but the Partners invested considerable time in informal processes. Personal knowledge of the performance of each store, the manager and the staff was important and remained a constant feature of the business throughout the period. Partners attended the District social events where they met both managers and Superintendents. Partners also visited the shops frequently. AD Power's appointment as a Partner in 1911 was partly because 'two Partners and a third doubtful one would be tied to the office in London more that they ought to be if personal knowledge of the branches is to be maintained. ${ }^{97}$ David Smith aimed to visit every shop within a threeyear period. ${ }^{98}$ Partners visited with relevant statistics. ${ }^{99}$ Visits were unannounced and the main purpose was to understand how well they were run - something which, one recalled, became clear as soon as entering the door. ${ }^{100}$ However, there was also a ceremonial element to them which reinforced the role of the family. One former manager recalled how 'we would bow Lord Hambleden in and bow Lord Hambleden out.' ${ }^{101}$

Rewarding and motivating performance

Across the business, salaries ranged from $100 \%$ fixed to $100 \%$ variable depending upon the nature of the role (see table 4).

Table 4: WHS basis for remuneration (near here) 
High levels of variable pay aligned the objectives of the store managers with those of the Partners. WHS incentivised managers based on their absolute profit/ sales rather than growth. Like the Partners, there is no evidence that this promoted risk taking. This was perhaps because managers were charged a cost of capital or because they prized steady earnings.

There were no competitions, prizes or other incentives to promote objectives. Newsbasket did not publish comparative results nor mentioned the performance of high performing individuals. While the regular visits of Partners may have motivated performance, it was a personal and individualised form of motivation.

\section{Measuring performance (key performance measures)}

The firm used a narrow selection of accounting sourced measures. In a major review of 'Organisation and Accounting' in 1958, consultants were particularly critical of the performance management information which they argued had hardly changed since the turn of the century and required interpretation by a trained accountant. ${ }^{102}$ Their criticism of the measures should not have come as a surprise to the Partners. Superintendents in the 1930's had complained about the lack of store profit information available to them. ${ }^{103}$ Similarly, when the Bank of England wrote to WHS in 1931 requesting certain statistical data, the minutes recorded that the Partners had to 'decline politely the request owing to the difficulty of providing information that would be accurate. ${ }^{104}$ Neither request triggered any action to improve the range of measures.

Annual aggregate statistics were recorded in the Statistical Book (1910 to 1958) but held only limited information, were inconsistent between the different store formats and went through very little change over the period (see table 5). 
Table 5: Measures included in the WHS Statistical Book and the first year they were recorded. (near here)

Outside the Statistical Book, the principal focus was on the use of capital. More statistics were gathered from store submissions on stock than on any other metric. ${ }^{105}$ Stock measures were widely quoted in correspondence between the Balance Department and store managers, usually to challenge the level of stocks held and to the annoyance of at least one store manager 'recognising as we do that stock must have a reasonable relationship to turnover.' 106

The one notable exception to the focus on financial measures was employee length of service. Although not included in any of the statistical books, Newsbasket frequently referred to the length of service of employees in articles or in quoting speeches. ${ }^{107}$ Length of service also determined attendance at social events where, symbolically, only those with 21 years' service were invited to the company-wide celebrations. ${ }^{108}$

\section{Linking the system}

If a performance management system existed at all within WHS, the various elements reflected a dysfunctional mix that seemed to work despite rather than because of itself. And, despite known limitations, went through almost no changes during the period. Organisational structures appear misaligned, there were few formal processes and those that existed were inconsistently applied across the business. There were relatively few measures and these were not applied consistently across business units. Instead, individuals were given considerable discretion to manage the business as they saw fit. However, while analysing the performance management system through each of the 
constituent parts is a practical way to understand how it operated, it ignores how the business managed performance as a whole. Was there a 'system', however loosely defined, which was more effective in managing the performance than simply the sum of the individual parts?

In 1920, Hornby gave a speech to celebrate the 100th anniversary of the firm in front of over 1,000 long serving employees. ${ }^{109}$ In defining the success of the business, he did not talk about its financial success, indeed, he did not mention a single financial statistic. He did not mention the size of the business - by number of shops it was one of the largest in the country. He made no reference to competitors, the economy or outside influence. His focus was on what made WHS special and he described:

\footnotetext{
'a certain innate quality and inherent strength of our business: It is just that "intangible thing" which it is so difficult to talk about, but which has been created during a long period of years by generations of Smith's men, and which is being created to-day by yourselves and ourselves and the initial credit for it is largely due to the founders of our business, the first WH Smith and his more distinguished son... I venture to say that their influence has permeated deeply into the inner life of our business, affecting unconsciously perhaps but still affecting the daily business lives of almost every one of us. ${ }^{110}$
}

At WHS, this "intangible thing", what we might now call culture, had evolved over the previous century and was sustained by traditions, rituals and the emphasis on family. It helped cement the relationship between the Partners and their often geographically distant employees which was neatly summarised in Hornby's testimonial to WFD Smith in 1928: 'To those who worked with him and for him he gave the fullest measure of trust, and he was repaid by such loyal service as few employers can boast of.'111 'Trust' and 'loyalty' were already well established themes by 1920; they had featured strongly in the first edition of Newsbasket in 1908 where the foreword referred to the 'loyalty' of the employees, the 'bond of union' and an 'esprit 
de corps.' They also remained important long after 1939, commented upon by external consultants in the 1950's and highlighted by directors in the 1970's. ${ }^{112}$

The importance of consistently promoting culture at WHS through speeches, articles and events suggests an alternative way to consider performance management and the constituent elements of a PMM system. Rather than focus on organisational structures and fixed processes held together by an integrated set of measures, performance can be managed through relationships and behaviours. At WHS, it was reflected in a system in which the Partners prided themselves on their personal knowledge of the business gained through store visits and personal contact but in which they otherwise entrusted management to manage themselves. In return they expected complete loyalty towards the aims of the business.

Viewed in this way, the practices at WHS appear more consistent and integrated. Practices which reinforced those behaviours were more developed - reward policies which aligned the objectives of managers and Partners, performance review policies which were based on individual performance (store and manager), personal interaction and focus on performance by exception. Conversely, those practices which did little to support the behaviours (or potentially undermined them) were less developed - formal and prescriptive company-wide processes, collective review of collective performance, comprehensive measurement systems. Indeed, any reader of Newsbasket in the 1920's or 1930's might suspect that length of service was the only important measure in the business and, given its association with trust and loyalty, perhaps it was?

\section{Conclusion}

The introduction highlighted that our understanding of PMM systems, despite 25 years of research, remains incomplete and that there are on-going challenges to the core principles. The introduction proposed looking back to understand how firms in the past 
managed performance. The findings show that many of the constituents of a modern system were not only present in the past but were aligned to the objectives of the organisation.

Boots and WHS are only two examples but their experiences help challenge some current thinking and highlight areas for further research. Not surprisingly given their different stages of development, there were significant differences in the approaches the two firms adopted to managing performance but there were also important similarities (see table 6).

\section{Table 6: Summary of Performance Management (near here)}

Firstly, as current literature suggests, the cases highlight that we need to be wary of placing too much emphasis on the role of measures in PMM systems. Early PMM literature recommended a broad set of specific measures which are adapted dynamically as the environment and strategy change. More recently, there have been calls for more subtlety in how measures are used in organisations and the need to consider more closely the environment in which the firms operate. ${ }^{113}$ The cases of Boots and WHS endorse the view. Both firms used a core set of measures in interactions with stores and did not add to these core measures over the period. This simplified communication of the primary objectives of the organisation. It also reduced the risk of measures becoming a constraint. In both firms the primary unit of performance was the store and these stores operated in a diverse range of environments - a small store in an affluent part of rural Oxfordshire faced different challenges from a large store in inner-city Manchester. Operating with a narrow range of core measures provided the flexibility for managers to tailor their approaches to their local environments. Melnyk et al., based on studies of current PMM systems, make a similar point although they argue that it is 
volatile environments changing over time rather than the differences between environments which encourages firms to maintain their existing set of measures. ${ }^{114}$ These findings highlight that in certain cases, retaining a general set of measures over long periods outweighs the advantages of changing them. However, our understanding of where these cases arise is still weak. Further research will allow us to add to these examples. Firms which operate across several different complex environments such as multi-national corporations or firms which delegate much of the decision making to their operating units may be particularly fruitful areas for research.

Secondly, in both firms, each director was expected to have a deep understanding of the overall performance of the business - a holistic perspective rather than a narrow functional one. For them, this meant understanding performance at the point that it was delivered to the customer - the store. Observing performance first hand by visiting stores, or receiving information directly from those who did (TGM's/ Superintendents) provided information beyond raw measures. It allowed the directors to qualitatively understand the impact of those drivers hard to measure (e.g. store manager capability) but, more importantly, how drivers interacted to deliver the objectives This approach contrasts with the more formal frameworks and scorecards of PMM systems. The findings cannot be dismissed as historical anomalies - both Mintzberg and Johnson stress the importance of directors having a deep personal understanding of the performance of the business and that this is best achieved by spending more time on 'the ground' and interacting with those responsible for delivering the performance. Johnson noted the benefits for senior managers - 'it shows a deep appreciation that results (and problems) ultimately emanate from and are explained by complex processes and concrete relationships, not by abstract quantitative relationships that describe results in simple, linear abstract terms. ${ }^{115}$ Johnson ascribes the approach to Japanese 
management techniques observed at Toyota but directors at both Boots and WHS would have recognised the practices.

The flat structure and the informal practices which brought directors and employees into close and regular contact not only helped improve understanding of performance but also helped link the system. In PMM systems, the objectives and strategy are communicated throughout the organisation by a set of linking measures. ${ }^{116}$ In both case studies, the need for measures as a tool for linking the performance management system was reduced by the flat structure and the regular interaction of the directors with the retail staff. Information flowed to the directors about performance but also flowed directly from the directors to the staff. This regular contact also fostered close relations between employees and directors and helped build a strong sense of loyalty towards the business and its objectives. The importance of these informal processes to PMM, both in terms of developing understanding and in building relationships, suggests further opportunities for research. This could include not only the processes themselves but also in the methods used by firms to promote such contacts - in modern retailers, for example, directors continue to visit stores extensively and to encourage contact between Head Office staff and stores. ${ }^{117}$ Plus ça change! 
Notes

${ }^{1}$ It remains one of the most cited articles of the Harvard Business Review ("Decades of Influence" Harvard Business Review, November 2012. Harvard Business Reviews 10 Must Reads: The Essentials. Cambridge, MA: Harvard Business Review Press, 2010.).

${ }^{2}$ Neely, "Revolution". In 2010, Taticchi et al. identified 6,618 articles published on performance measurement across 546 journals, 91\% published since 1991.

${ }^{3}$ Lebas, "Performance Measurement".

${ }^{4}$ Kaplan and Norton, "Using"; "Mastering".

${ }^{5}$ Bititci et al., "Integrated".

${ }^{6}$ Following Melnyk et al. "fit for the future".

${ }^{7}$ Bourne et al. "Emerging Issues"; Melnyk et al. "fit for the future"; Franco-Santos et al., "Contemporary".

${ }^{8}$ Johnson, "Former Management Accountant".

${ }^{9}$ Bourne et al. "Emerging Issues", 117; Bititci et al., "Challenges", 318.

${ }^{10}$ Bititci et al., "Challenges"; Bourne Handbook; Johnson and Kaplan, Relevance Lost; Ansoff, Implanting.

${ }^{11}$ Ferreira and Otley, "Design”.

${ }^{12}$ Otley, "Performance Management".

${ }^{13}$ Stringer, "Empirical".

${ }^{14}$ Scranton, "Beyond Chandler"; Evans, Defence of History; Bloch, Historians Craft.

${ }^{15}$ Maclean et al., "Conceptualizing"; 2016, Godfrey et al. "What is organisational history";

Decker et al. "New business histories"; Bucheli and Wadwhani, Organisations in Time.

${ }^{16}$ Kipping and Üsdiken, "More than meets the eye".

${ }^{17}$ David, Retail; McNair and David, Problems; McNair, Retail Distribution; McNair and Gragg, Retail Store Management; McNair et al., Problems in Retailing.

${ }^{18}$ Hodge, Retail Accounting, $\mathrm{x}$.

${ }^{19}$ Hayward and White, Chain Stores.

${ }^{20}$ Chandler, Scale; Fear, Organizing Control; Jones, Renewing.

${ }^{21}$ Grenier, "Evolution". 
${ }^{22}$ Retail Chemists." Financial Times [London, England] 24 Sept. 1907: 8. Financial Times. Web.

${ }^{23}$ Chapman, Jesse Boot.

${ }^{24}$ Greenwood, Cap argues that this was partly through failing health, a desire to fund a university in Nottingham and lack of confidence in his son.

${ }^{25}$ Hayward and White, Chain Stores.

${ }^{26}$ Chapman, Jesse Boot.

${ }^{27}$ The Bee, November 1921.

${ }^{28}$ BTC A 49/3 - Memorandum on the Peat Report by FA Cockfield, November 1966.

${ }^{29}$ The Bee, July 1925.

30 'Own Goods supplies grew by 34\% between 1930 and 1934 while overall sales were largely flat. BTC Finance Report (unreferenced).

${ }^{31}$ From $39.6 \%$ in 1922 to $48.5 \%$ in 1939 (BTC 461 - Statistical Books 1923/24 to 1941).

32 "The Development and Organisation of Boots Pure Drug Company Ltd" - an address to LSE March 1959 by Cockfield (unreferenced) and Greenwood (1977).

${ }^{33}$ The Bee, February 1924. Description of speech given by Gales in March 1923.

${ }^{34}$ John Boot and JE Greenwood (Greenwood 1977). The Bee reported a regular flow of senior managers across the Atlantic, especially in the early 1920's (The Bee, December 1921; July 1923; March 1927; Memo's re TGM's (BTC A361/3).

${ }^{35}$ Greenwood, Cap.

36 "Boots Pure Drug Report." Financial Times [London, England] 9 May 1923: Financial Times. Web.

${ }^{37}$ The Bee, March 1922.

${ }^{38}$ Greenwood, Cap.

${ }^{39}$ Chapman, Jesse Boot; The Bee, January 1922; BTC 345/2 Expenses Report.

${ }^{40}$ The Bee, March 1922.

${ }^{41}$ The Bee, December 1922.

4219 Territories in 1922 (The Bee, September 1922) and 28 in 1939 (BTC 461 - Statistical Books 1923/24 to 1941).

${ }^{43}$ BTC A 361/3 Memo's re TGM's (5 August 1920). 
${ }^{44}$ The Bee, August 1922.

${ }^{45}$ BTC A 361/3 Memo's re TGM's (5 August 1920).

${ }^{46}$ BTC A 89/33 - Role of the Territorial General Managers (undated but c. mid-1930's).

${ }^{47}$ BTC A 361/3 Memo's re TGM's (31 April 1924).

48 BTC 2555/1 The Corporate Plan 1978.

${ }^{49}$ BTC A $89 / 33$.

${ }^{50}$ The Bee, September 1922; September 1923.

${ }^{51}$ The Bee, February 1922; March 1923.

${ }^{52}$ The Bee, July 1922 - all but 27 stores submitted on time.

${ }^{53}$ BTC A $89 / 33$.

${ }^{54}$ BTC 298 - Personnel file of store manager. The only copy relates to 1940 but the log starts in 1922.

${ }^{55}$ The Bee, March 1928 includes a humorous version.

${ }^{56}$ Based on entries in the logs on the personnel files of store managers (BTC 298).

${ }^{57}$ The Bee, December 1922.

${ }^{58}$ The Bee, December 1922.

${ }^{59}$ The Bee, March 1936.

${ }^{60}$ Greenwood, Cap. Greenwood only refers to the Executive but based on accounting reports, bonuses were also payable to senior managers (including TGM's).

${ }^{61}$ BTC A 129/7 - Various Memo's TGM's.

${ }^{62}$ BTC 780/5 - Sales and Increased Sales Bonus Scheme (1 March 1936).

${ }^{63}$ BTC A 129/ 2 - Various memos to TGM's and Branch Mgrs (Burton store February and August 1921).

${ }^{64}$ The Bee, March 1922.

${ }^{65}$ The Bee, September 1922.

${ }^{66}$ The Bee, September 1922

${ }^{67}$ Greenwood, Cap.

${ }^{68}$ The Bee, March 1922. 
${ }^{69}$ Even the 'Expense Report' had as many pages devoted to sales as expenses. BTC 345/2 Expense Report 12 months ended March 31, 1932.

${ }^{70}$ BTC A 48/1; The Bee, November 1928 and frequently thereafter.

${ }^{71}$ The Bee, April 1924.

${ }^{72}$ Explanations for creating the TGM structure. BTC A 361/3 Memo's re TGM's (5 August 1920).

${ }^{73}$ The Bee, December 1922.

${ }^{74}$ The Bee, March 1922.

${ }^{75}$ Newsbasket, July 1960.

${ }^{76}$ Wilson, First.

${ }^{77}$ Memo from Bircham \& Co WHS 912/7, 8 October 1936.

${ }^{78}$ WHS 215 minute book: 26/11/23, 24/09/25, 25/9/29 and WHS Y 119: 7/7/31

${ }^{79}$ WHS 452 - Letter from G Marshall to the Partners 21/2/1930 (Manager of Stationery

Department)

${ }^{80}$ WHS PA 44550 Years in the Book trade. Reminiscences of AD Power. Undated but c. mid1950's.

${ }^{81}$ WHS Q 14 Reminiscences: Non-executive director (1910-87).

${ }^{82}$ Numbers varied over the period but there was never more than seven.

${ }^{83}$ Letter from Hornby to Power referred to in the written reminiscences of AD Power: 50 Years in the Book trade (WHS PA 445).

${ }^{84}$ Minute Book 22 June 1931 (WHS Y 118).

${ }^{85}$ Minute Book 29 June 1931 (WHS Y 118).

${ }^{86}$ WHS Q 17 Reminiscences: A J Watson (1916-82) \& C G Baker (1916-2000) (Area Managers to 1978/79) recorded 15 Aug 1979.

${ }^{87}$ Balance sheet and accounts WHS X 161. Their share of profit ranged between $30 \%$ and $60 \%$ over the period.

${ }^{88}$ Talking Shop, January 1951 in an article written by the Accounts department to explain their structure and role.

${ }^{89}$ WHS 215 Partners Minute Book: 1911 - 1933 (2 December 1921).

${ }^{90}$ WHS 798: Retail Practices Report 29 June 1956. 
${ }^{91}$ WHS 798: Retail Practices Report 29 June 1956.

${ }^{92}$ History of the firm in a Newsbasket supplement October 1920.

${ }^{93}$ WHS 156: Cheap Books Scheme; WHS Y 119 - Minute Book 1931/32 (29 February 1932 and 2 May 1932); WHS Y 120 - Minute Book 1933/35 (10 December 1934).

94 'WH Smith \& Son Ltd. Study of Internal Performance Years 1960/61 to 1967/68' conducted by Peat Marwick, included in WHS 554.

95 WHS 285: Photo/ letters/ speeches M Hornby.

${ }^{96}$ WHS Q 10 Reminiscences: K A Jessup (1914-2002), H A Johnston (1907-81); W Spicer (1909-81), C E Woodhurst (1910-88); recorded 14 Feb 1979.

${ }^{97}$ WHS 87/1 Letters on ADP partnership 1910 - 1911, 1923, 1928.

${ }^{98}$ WHS Q 17.

${ }^{99}$ WHS Q 31 Reminiscences: P W Bennett (1917-96); May 1982.

${ }^{100}$ WHS Q 9: Reminiscences: Lady Helen Smith (1908-2003); 10 January 1979.

101 WHS Q 17.

${ }^{102}$ Report No. 17: (30/4/58). Part of WHS 799: Organisation and Accounting (10 September 1956).

${ }^{103}$ Memo to Partners from Superintendent Conference January 1932. Part of WHS 588

Minutes/Papers: Directors' Informal Meetings; 1952-55.

${ }^{104}$ WHS Y 119 - Minute Book 1931/32 (14 December 1931).

${ }^{105}$ Stock turnover by product group, stock age, number of stock lines and stock depreciation. WHS X 3 Balance sheets and accounts: 19 A shops various years (1920 - 1958).

${ }^{106}$ Bournemouth store manager 31 May 1929. WHS X 3.

${ }^{107}$ For example - Newsbasket October 1920 included a list of the employees with more than 50 year's service, January 1922 there is a description of a dinner where the average length of service of the 65 guests was 24 years, May 1922 there is a photo of the 25 members of the Newspaper dispatch department who had an average length of service of 46 years.

${ }^{108}$ WHS Q 15 Reminiscences: Hon. J Smith (1906-80); 26 June 1979.

109 The firm was more than 120 years old but they were not aware at the time. Long serving defined as more than 21 year's service, about $10 \%$ of the workforce.

${ }^{110}$ Newsbasket November 1920. 
111 Newsbasket July 1928.

112 WHS 799 - Organisation and Accounting Report No. 4, 1956 and Q series of reminiscences.

${ }^{113}$ Bourne et al., "Emerging Issues".

${ }^{114}$ Melnyk et al. "Fit for the future".

115 Johnson, Lean Dilemma, 8. Mintzberg has consistently argued that directors need to spend more time with employees and observe first-hand how the business is operating, e.g. Mintzberg, Musings; Managing; on management.

${ }^{116}$ Franco-Santos et al, Contemporary.

${ }^{117}$ At Walmart, the CEO explained at a strategic update on 1 April 2015 that he had spent his first 8 months visiting and working in stores (https://seekingalpha.com/article/3046106walmart-stores-wmt-u-s-strategic-update-conference-call-transcript). At Tesco, the new Chief Executive initiated a programme in 2014 requiring every member of Head Office to spend a day a fortnight in store over a three-month period (The Grocer 1 October 2014 http://www.thegrocer.co.uk/channels/supermarkets/tesco/dave-lewis-orders-tesco-hq-staff-backto-shop-floor/372088.article)

\section{References}

Ansoff, I.H. Implanting Strategic Management. Englewood Cliffs, NJ: Prentice Hall, 1984.

Bititci, U.S., P. Garengo, V. Dörfler, and S. Nudurupati. "Performance Measurement: Challenges for tomorrow." International Journal of Management Reviews 14 (2012): 305-327.

Bititci, U., A. Carrie, and L. McDevitt. "Integrated Performance Measurement Systems: A Development Guide." International Journal of Operations \& Production Management 26 no. 11-12 (1997): 1325-1350.

Bloch, M. The Historians Craft Manchester: University Press, 1954.

Bourne, M., Melnyk, S., Bititci, U., Platts, K. and B. Andersen "Emerging issues in performance measurement” Management Accounting Research, 25, 2, (2014): $117-118$

Bourne, M. (ed.) The Handbook of Performance Measurement. London: Gee Publishing, 2001. 
Bucheli, M. and D. Wadhwani. Organizations in Time. Oxford Scholarship Online, 2014.

Chandler, A.D Jr. Scale and Scope. The Dynamics of Industrial Capitalism. Cambridge, MA: Belknap Press, 1990.

Chapman. S. Jesse Boot of Boots the Chemists: A Study in Business History. London: Hodder and Stoughton, 1974.

David, D. Retail Store Management Problems. New York: AW Shaw, 1922.

Decker, S., Kipping, M., and D. Whadhwani "New business histories! Plurality in business history research methods" Business History 57, (1) (2015): 30-40.

Evans, R. In Defense of History London: Granta Books, 1997.

Fear, J. Organizing Control: August Thyssen and the Construction of German Corporate Management. Cambridge, MA: Harvard University Press, 2005.

Ferreira, A., and D. Otley. "The design and use of performance management systems: An extended framework for analysis." Management Accounting Research 20, 4, (2009): 263-282.

Franco-Santos, M., L. Lucianetti, and M. Bourne. "Contemporary performance measurement systems: A review of their consequences and a framework for research" Management Accounting Research 23 (2012): 79-119.

Godfrey, P., Hassard, J., O’Connor, E., Rowlinson, M., and M. Ruef "What is Organizational History? Toward a creative synthesis of history and organisation Studies" Academy of Management Review, 41, 4, (2016): 590 - 608

Greenwood, J. A Cap for Boots. London: Hutchinson Benham, 1977.

Grenier, L. "Evolution and Revolution as Organisations Grow." Harvard Business Review, 50, 4, (1972): 37 - 46

Hayward, W., and P. White. Chain Stores. New York: McGraw-Hill, 1922.

Hodge, A.C. Retail Accounting and Control. Chicago: University of Chicago Press, 1925.

Johnson, H.T. "Lean Dilemma: Choose System Principles or Management Accounting Controls, Not Both.” In Lean Accounting: Best Practices for Sustainable Integration, edited by J. Stenzel, 3-16. Hoboken, NJ: John Wiley, 2007. 
Johnson, H.T. “A Former Management Accountant Reflects on his Journey through the World of Cost Management.” Accounting History 7, 1, (2002): 9-21.

Johnson, H.T., and R.S. Kaplan. Relevance Lost: The Rise and Fall of Management Accounting. Harvard: Harvard Business School Press, 1987.

Jones, G. Renewing Unilever: Transformation and Tradition Oxford: Oxford University Press, 2005.

Kaplan, R.S., and D. Norton. "The Balanced Scorecard - Measures that Drive Performance." Harvard Business Review 70, 1, (1992): 71-79.

Kaplan, R.S., and D.P. Norton. "Using the balanced scorecard as a strategic management system.” Harvard Business Review 74 no. 1, (1996): 75-85.

Kaplan, R.S., and D.P. Norton. "'Mastering the management system.' Harvard Business Review 86, no. 1, (2008): 62-77.

Kipping, M. and B. Üsdiken, "History in Organisation and Management Theory: More than Meets the Eye." The Academy of Management Annals, 8:1, (2014): 535588.

Lebas, M. J. "Performance measurement and performance management." International Journal of Production Economics 41, no. 1-3: (1995): 23-35.

Maclean, M., Harvey, C., and S. Clegg, "Conceptualizing Historical Studies” Academy of Management Review, 41, 4, (2016): 609-632.

Melnyk, S., Bititci, U., Platts, K., Tobias, J., and B. Andersen "Is performance measurement and management fit for the future?" Management Accounting Research, 25, 2 (2014): 173-186

Mintzberg, H. Managing. Harlow: Prentice Hall, 2009

Mintzberg, H. Musings on Management, Harvard Business Review, 74, 4, (1996): 61 67.

Mintzberg, H. Mintzberg on Management: Inside out strange world of Organisation. New York: Macmillan, 1989.

Neely, A. "The performance measurement revolution: why now and what next?" International Journal of Operations \& Production Management 19, 2, (1999): 205-228. 
McNair, M.P., and D. David. Problems in Retailing. New York: AW Shaw Company, 1926.

McNair, M.P. Problems in Retail Distribution. New York: McGraw-Hill, 1930.

McNair, M.P., and C.I. Gragg. Problems in Retail Store Management. New York: McGraw-Hill, 1931.

McNair, M.P., C.I. Gragg, and S. Teele. Problems in Retailing. New York: McGrawHill, 1937.

Otley, D. "Performance management: a framework for management control systems research" Management Accounting Research, 10, 4, (1999): 363-382.

Scranton, P. "Beyond Chandler" Enterprise and Society, 9, 3, (2008): 426-429

Stringer, C. "Empirical performance management research: observations from AOS and MAR" Qualitative Research in Accounting \& Management, 4, 2, (2007): 92114.

Taticchi, P., F. Tonelli, and L. Cagnazzo. "Performance measurement and management: a literature review and a research agenda." Measuring Business Excellence 14, 1, (2010): 4-18.

Wilson, C. First with the News, the History of WH Smith 1792 - 1972, London: Jonathan Cape, 1985.

Table1: Framework

\begin{tabular}{|l|l|}
\hline Performance objectives & $\begin{array}{l}\text { Questions } \\
\text { organisation's overall future success and how were } \\
\text { they brought to the attention of managers and } \\
\text { employees? }\end{array}$ \\
\hline Organisational structure & $\begin{array}{l}\text { What was the organisation structure and what impact } \\
\text { did it have on the design and use of performance } \\
\text { management structures and systems? How did it }\end{array}$ \\
\hline
\end{tabular}




\begin{tabular}{|c|c|}
\hline & $\begin{array}{l}\text { influence and how was it influenced by the } \\
\text { performance management processes? }\end{array}$ \\
\hline \multicolumn{2}{|c|}{ Performance management processes: } \\
\hline $\begin{array}{l}\text { - Planning and targeting } \\
\text { performance }\end{array}$ & $\begin{array}{l}\text { What strategies and plans did the organisation adopt } \\
\text { and what were the processes and activities that it } \\
\text { decided were required for it to ensure success? How } \\
\text { did it go about setting appropriate performance targets } \\
\text { for its key performance measures? }\end{array}$ \\
\hline - Evaluating performance & $\begin{array}{l}\text { What processes (formal and informal) did the business } \\
\text { use to evaluate individual, group, and organisational } \\
\text { performance? Were performance evaluations primarily } \\
\text { objective, subjective or mixed? }\end{array}$ \\
\hline $\begin{array}{ll}\text { - } & \text { Motivating (including } \\
\text { rewarding) performance }\end{array}$ & $\begin{array}{l}\text { How did the firm motivate employees to deliver the } \\
\text { performance of the business? What was the mix of } \\
\text { financial and non-financial rewards? }\end{array}$ \\
\hline Measuring performance & $\begin{array}{l}\text { What were the key performance measures? How } \\
\text { frequently did they change? How were they specified } \\
\text { and communicated and what role do they play in } \\
\text { performance evaluation? Were there significant } \\
\text { omissions? }\end{array}$ \\
\hline Linking the system & $\begin{array}{l}\text { How were the separate structures and systems linked } \\
\text { (if at all)? How strong were those links? How did they } \\
\text { change over time? }\end{array}$ \\
\hline \multicolumn{2}{|c|}{$\begin{array}{l}\text { Sources: Ferreira and Otley, "The design and use of performance management } \\
\text { systems"; Otley, "Performance management: a framework for management control } \\
\text { systems research"; Stringer, "Empirical performance management research". }\end{array}$} \\
\hline
\end{tabular}

Table 2: Chronological Summary

\begin{tabular}{|l|r|r|}
\hline Boots & Date & WHS \\
\hline 1792 & Firm founded by HW Smith selling \\
newspapers in London.
\end{tabular}




\begin{tabular}{|c|c|c|}
\hline & 1848 & $\begin{array}{r}\text { Start multiple retailing after they contract } \\
\text { with London \& North-Western Railway to } \\
\text { operate bookstalls on station concourses. } \\
\text { Contracts follow with other railway } \\
\text { companies. By 1902, they had } 779 \\
\text { bookstalls. }\end{array}$ \\
\hline & 1853 & $\begin{array}{r}\text { Open first regional Wholesale House } \\
\text { (Birmingham). More follow and by } 1920 \\
\text { there were } 36 \text { Wholesale Houses. }\end{array}$ \\
\hline $\begin{array}{l}\text { Jesse Boot leaves school at } 13 \text { and works } \\
\text { full time in the family shop in Nottingham } \\
\text { selling herbal remedies. }\end{array}$ & 1863 & \\
\hline $\begin{array}{l}\text { Firm incorporated as Boot and Company } \\
\text { Limited selling a range of products } \\
\text { including proprietary medicines. }\end{array}$ & 1883 & \\
\hline $\begin{array}{l}\text { Becomes a public limited company (Boots } \\
\text { Pure Drug Company) with four branches. } \\
\text { Boot holds the controlling shares. Expands } \\
\text { rapidly through organic growth and } \\
\text { acquisition. By 1900, they had } 181 \text { stores. }\end{array}$ & 1888 & \\
\hline \multirow[t]{2}{*}{$\begin{array}{l}\text { Develops a larger store format by creating } \\
\text { a departmental structure offering a } \\
\text { dispensary, perfumeries, toiletries and } \\
\text { 'fancy goods'. }\end{array}$} & 1891 & $\begin{array}{r}\text { WFD Smith (1868 - 1928) succeeds his } \\
\text { father as head of the business. His good } \\
\text { friend, CH St J Hornby becomes a Partner } \\
\text { in } 1894 \text { (and retires in 1946). }\end{array}$ \\
\hline & 1905 & $\begin{array}{l}\text { Loss of two railway contracts leads to the } \\
\text { opening of high street stores. By the end of } \\
1908 \text {, they have more than } 200 \text { stores } \\
\text { generating half the sales of the bookstalls. }\end{array}$ \\
\hline $\begin{array}{l}\text { Jesse Boot sells the whole business to } \\
\text { United Drug Company of the United } \\
\text { States. Jesse Boot remains as nominal head } \\
\text { of the business. His son (John) has } \\
\text { effective operational control as head of the } \\
\text { Executive Committee. }\end{array}$ & 1920 & \\
\hline Statistics & $1920 / 21$ & \\
\hline Retail Sales (£’000) & & 4,129 \\
\hline Group Profit (£’000) & & 287 \\
\hline \multirow[t]{3}{*}{ Number of stores } & & 853 \\
\hline & 1928 & $\begin{array}{l}\text { WFD Smith dies. Succeeded by WH } \\
\text { Smith (1903 - 1948), his eldest son. }\end{array}$ \\
\hline & 1929 & $\begin{array}{l}\text { WHS becomes a private limited company. } \\
\text { Shares held by the Smith family. }\end{array}$ \\
\hline Statistics & $1930 / 31$ & \\
\hline
\end{tabular}




\begin{tabular}{|c|c|c|c|}
\hline Retail Sales (£’000) & \multicolumn{2}{|l|}{10,094} & 4,461 \\
\hline Group Profit (£’000) & \multicolumn{2}{|l|}{674} & 133 \\
\hline Number of stores & \multicolumn{2}{|l|}{911} & 926 \\
\hline \multicolumn{2}{|c|}{$\begin{array}{l}\text { Boots sold and becomes a public limited } \\
\text { company with John Boot as Chairman. }\end{array}$} & 1933 & \\
\hline \multicolumn{2}{|l|}{ Statistics } & \multicolumn{2}{|c|}{$1939 / 40$} \\
\hline Retail Sales (£’000) & \multicolumn{2}{|l|}{13,777} & 4,876 \\
\hline Group Profit (£’000) & \multicolumn{2}{|l|}{720} & 201 \\
\hline Number of stores & \multicolumn{2}{|l|}{1,210} & 999 \\
\hline \multicolumn{4}{|c|}{$\begin{array}{l}\text { Sources: Chapman, Jesse Boot; Wilson, First with the News; Greenwood, Cap; BTC } 461 \text { - } \\
\text { Statistical Books; WHS X } 15 \text { - Statistical Book. }\end{array}$} \\
\hline
\end{tabular}

Table 3: Boots key performance measures - retail measures reported on the summary page of the Statistical Book (selected years)

\begin{tabular}{|l|c|c|c|}
\hline Measure (current and prior year) & $\mathbf{1 9 2 5}$ & $\mathbf{1 9 3 0}$ & $\mathbf{1 9 3 9}$ \\
\hline Sales (£): & $\checkmark$ & $\checkmark$ & $\checkmark$ \\
\hline Expenses (£) & - & $\checkmark$ & $\checkmark$ \\
\hline Salaries (£) & $\checkmark$ & $\checkmark$ & $\checkmark$ \\
\hline Number of employees & $\checkmark$ & $\checkmark$ & $\checkmark$ \\
\hline Customer transactions (no.) & $\checkmark$ & $\checkmark$ & $\checkmark$ \\
\hline Average value per customer transaction (£) & $\checkmark$ & $\checkmark$ & $\checkmark$ \\
\hline One penny per customer (£) & $\checkmark$ & $\checkmark$ & $\checkmark$ \\
\hline Number of branches & $\checkmark$ & $\checkmark$ & $\checkmark$ \\
\hline Number of branches opened in the year & $\checkmark$ & $\checkmark$ & $\checkmark$ \\
\hline Number of branches closed in the year & & $\checkmark$ & $\checkmark$ \\
\hline Comparative shops (open two complete years) & $\checkmark$ & $\checkmark$ & $\checkmark$ \\
\hline Retail sales (£) & $\checkmark$ & $\checkmark$ & $\checkmark$ \\
\hline Customer transactions (no.) & $\checkmark$ & $\checkmark$ & $\checkmark$ \\
\hline Average value per customer transaction (£) & $\checkmark$ & $\checkmark$ & $\checkmark$ \\
\hline a Potential increase in total sales for each penny increase in the average transaction value & $\checkmark$ & $\checkmark$ \\
\hline Source: BTC 461 - Statistical Books 1923/24 to 1941 & & $\checkmark$ & $\checkmark$ \\
\hline
\end{tabular}

Table Error! Main Document Only.: WHS basis for remuneration

\begin{tabular}{|l|l|l|}
\hline & Basis & Variable pay basis \\
\hline Smith family & Primarily fixed & \\
\hline
\end{tabular}




\begin{tabular}{|l|l|l|}
\hline $\begin{array}{l}\text { Partners and Departmental } \\
\text { Managers }\end{array}$ & $\begin{array}{l}\text { Fixed salaries but } \\
\text { also a potentially } \\
\text { large variable } \\
\text { element }\end{array}$ & $\begin{array}{l}\text { Share (up to 10\%) of the Firm/ } \\
\text { Departmental profit after cost of } \\
\text { capital. }\end{array}$ \\
\hline $\begin{array}{l}\text { 'A' Store/ Wholesale House } \\
\text { Managers }\end{array}$ & $\begin{array}{l}\text { Primarily variable } \\
\text { (up to 100\%) }\end{array}$ & $\begin{array}{l}\text { Share (typically 20\%) of their } \\
\text { store/ wholesale house profit after } \\
\text { cost of capital. }\end{array}$ \\
\hline 'B' Store/ Bookstall Manager & $\begin{array}{l}\text { Primarily variable } \\
\text { (up to 100\%) }\end{array}$ & $\begin{array}{l}\text { Share (up to 5\%) of their store } \\
\text { sales. }\end{array}$ \\
\hline Store staff & Fixed & $\begin{array}{l}\text { Sales commission was introduced } \\
\text { in 1933 but soon abandoned }\end{array}$ \\
\hline $\begin{array}{l}\text { Source: WHS 1090: Review of Retail Managers Pay Structure; WHS 215 Partners Minute Book 1911 } \\
-1933 .\end{array}$
\end{tabular}

Table 5: Measures included in the WHS Statistical Book and the first year they were recorded.

\begin{tabular}{|l|c|c|c|}
\hline & 'A' Stores & 'B' Stores & Bookstalls \\
\hline £ annual sales and \% growth in sales & 1914 & 1914 & 1910 \\
\hline $\begin{array}{l}\text { £ sales by type of merchandise (at } \\
\text { cost price) }\end{array}$ & 1938 & Never & Never \\
\hline $\begin{array}{l}\text { £ sales by type of merchandise (at } \\
\text { selling price) }\end{array}$ & Never & 1914 & 1910 \\
\hline \% gross margin & 1914 & Never & Never \\
\hline $\begin{array}{l}\text { £ expenses by type of expense and \% } \\
\text { ratio to sales }\end{array}$ & 1914 & 1914 & 1910 \\
\hline £ and \% net profit & 1914 & Never & Never \\
\hline Stock turnover & Never & 1929 & 1929 \\
\hline Debt (on credit sales) by age & Never & 1929 & 1929 \\
\hline Cash deficiencies and overpayments & Never & 1914 & 1910 \\
\hline Source: WHS X 15 Statistical Book 1910 - 1958 & & \\
\hline
\end{tabular}

Table 6: Summary of Performance Management

\begin{tabular}{|l|ll|l|}
\hline & \multicolumn{1}{|c|}{ Boots } & \multicolumn{1}{c|}{ WHS } \\
\hline $\begin{array}{l}\text { Performance } \\
\text { objectives }\end{array}$ & $\bullet \quad$ Sales Growth & $\begin{array}{l}\text { Capital maintenance and a steady } \\
\text { return on capital }\end{array}$ \\
\hline $\begin{array}{l}\text { Organisational } \\
\text { structure }\end{array}$ & $\bullet \quad \begin{array}{l}\text { New structure created in 1920/21 } \\
\text { based on the existing retail structures } \\
\text { of the parent company. }\end{array}$ & $\begin{array}{l}\text { Structure evolved over the previous } \\
\text { century. Little alignment between } \\
\text { different parts of the business. }\end{array}$ \\
\hline
\end{tabular}




\begin{tabular}{|c|c|c|}
\hline & $\begin{array}{l}\text { Flat structure }- \text { only one tier of } \\
\text { management between stores and } \\
\text { directors (the TGM). } \\
\text { Little change in structure over the } \\
\text { period. }\end{array}$ & $\begin{array}{l}\text { Flat structure - the largest } \\
\text { businesses ('A' stores/ Wholesale } \\
\text { Houses) reported directly to the } \\
\text { Partners. Two tiers between smaller } \\
\text { stores and the Partners. } \\
\text { - Little change in structure over the } \\
\text { period. }\end{array}$ \\
\hline \multicolumn{3}{|c|}{ Performance management processes: } \\
\hline $\begin{array}{l}\text { Planning and } \\
\text { targeting } \\
\text { performance }\end{array}$ & $\begin{array}{l}\text { Evidence of long term planning } \\
\text { aligned to objectives but no formal } \\
\text { processes. } \\
\text { No budgets but control over costs } \\
\text { through standards. }\end{array}$ & $\begin{array}{l}\text { - No formal processes. Investment } \\
\text { influenced by crises/ opportunities } \\
\text { and the initiative of employees. } \\
\text { - No budgets/standards. }\end{array}$ \\
\hline $\begin{array}{l}\text { Evaluating } \\
\text { performance }\end{array}$ & $\begin{array}{l}\text { Formal review: } \\
\text { Directors undertook a collective } \\
\text { review of performance at least } \\
\text { weekly. Review involved direct input } \\
\text { from TGM's though a weekly report } \\
\text { to the Chairman and attendance at the } \\
\text { weekly Executive meeting } \\
\text { - Informal qualitative evaluations: } \\
\text { Regular store visits by directors to } \\
\text { stores aiming to get a holistic } \\
\text { understanding of the performance } \\
\text { of the business. }\end{array}$ & $\begin{array}{l}\text { - Formal review: } \\
\text { Partners individually met } \\
\text { Superintendents monthly and 'A' } \\
\text { store/ Wholesale House managers } \\
\text { annually. } \\
\text { - Informal qualitative evaluations: } \\
\text { Regular store visits by directors to } \\
\text { stores aiming to get a holistic } \\
\text { understanding of the performance } \\
\text { of the business. }\end{array}$ \\
\hline $\begin{array}{l}\text { Motivating } \\
\text { (including } \\
\text { rewarding) } \\
\text { performance }\end{array}$ & $\begin{array}{l}\text { - } \\
\text { - Higned to performance objectives. } \\
\text { remuneration. } \\
\text { - Variable element based on growth in } \\
\text { sales. } \\
\text { - Use of a broad range of symbolic } \\
\text { incentives. }\end{array}$ & $\begin{array}{l}\text { - } \\
\text { - Low figned to performance objectives. } \\
\text { remuneration (with exceptions). } \\
\text { - Variable element based on absolute } \\
\text { profit or sales. }\end{array}$ \\
\hline $\begin{array}{l}\text { Measuring } \\
\text { performance }\end{array}$ & 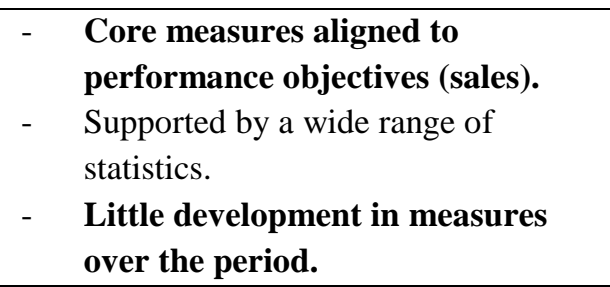 & 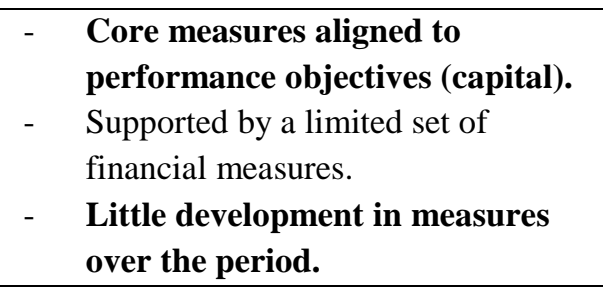 \\
\hline Linking the system & $\begin{array}{l}\text { Informal regular contacts between } \\
\text { senior managers and store staff } \\
\text { facilitating on-going } \\
\text { communication of objective. } \\
\text { Emphasis on loyalty to align } \\
\text { employees to objective. }\end{array}$ & $\begin{array}{ll}\text { - Informal regular contacts between } \\
\text { senior managers and store staff } \\
\text { facilitating on-going } \\
\text { communication of objective. } \\
\text { - Reliance on a common culture to } \\
\text { align employees to objective. }\end{array}$ \\
\hline
\end{tabular}

